\title{
The Enlightened Conservatism of the Malabar Missions: Gaston-Laurent Courdoux (1691-1779) and the Making of an Anthropological Classic
}

\author{
Carolina Armenteros
}

Pontificia Universidad Católica Madre y Maestra/Wolfson College, University of Cambridge c.armenteros81@gmail.com

\begin{abstract}
Few authors of scholarly classics shy away from being acknowledged, but such is the case of the author of Mours et coutumes des Indiens (Mores and customs of the Indians) (1777) — the first treatise of Indology and a classic of early anthropology — whose real, Jesuit identity remained obscured for over two centuries. The author's concealment did not, however, prevent his work's regular re-editing, or its conveyance of an original methodology that helped found ethnography as a discipline and harmonized with enlightened conservatism. To date, this methodology has been read simply as a direct reply to enlightened authors, especially Voltaire, but this essay demonstrates that it derived also from the immersion of eighteenth-century Jesuits in Indian culture, and above all from the vast Indianist tradition that members of the Society of Jesus developed over two centuries of missionary work. Indeed, the story of Mours et coutumes discloses that, far from being limited to Europe, enlightened conservatism was a global discourse; and that beyond being invented by Europe's armchair philosophers, anthropology was a science born outside Europe from the pens of missionaries.
\end{abstract}

\section{Keywords}

Jesuits - Society of Jesus - Gaston-Laurent Cœurdoux (1691-1779) - history of anthropology - history of ethnography - Mours et coutumes des Indiens 
Few authors of scholarly classics shy away from being acknowledged, but such is the case of the author of Moeurs et coutumes des Indiens (Mores and customs of the Indians ) - the first treatise of Indology and a classic of early anthropology - whose real identity remained obscured for over two centuries. ${ }^{1}$ That the mystery endured so long is partly due to the fact that the text twice appeared under different names: at first that of the Pondicherry cavalry officer NicolasJacques Desvaulx (1745-1817), who published it in France in 1777, and later that of the director of the Paris Foreign Missions, Abbé Jean-Antoine Dubois (17651848). It was Dubois who brought the work to fame by translating it into English as his own work and selling it to the British for the then-huge sum of £8oo under the title Description of the Character, Manners and Customs of the People of India, and of Their Institutions, Religious and Civil (1816). By 1924, the work had seen at least three editions and been issued ten times. Dubois, however, did not simply reproduce Coeurdoux's work but added material to the original manuscript, which Quentin Garreau speculates was itself derived from the "treasure" of Indianist manuscripts that the Jesuits compiled and that scholars until now thought had been lost on the dissolution of the Society of Jesus. ${ }^{2}$

The original reason why Mours et coutumes' true author remained concealed was probably not, however, intellectual theft: it is very possible that Desvaulx first published the manuscript under his name with the real author's consent. The reason for the concealment was rather the state of shame and ignominy in which the former members of the Society of Jesus found themselves after Pope Clement XIV (r.1769-74) dissolved the Society in 1773. With the Jesuits' India missions lost to their long-standing enemies, the Foreign Missions, it may very well be that Father Gaston-Laurent Cœurdoux (1691-1779), the Jesuit from Bourges whom Sylvia Murr (1947-2002) finally identified in the 1970 s as Mours et coutumes' real author, handed the text over to Desvaulx, a loyal supporter of the Society, so that the young officer could publish it under his own name and, in this manner, smuggle the missionary message of

1 The oft-employed misnomer "Malabar missions" refers here to the missions that the Society of Jesus built throughout the eighteenth century not only on the Malabar coast - the site of the first, sixteenth-century missions - but throughout today's Karnataka and Tamil Nadu in the regions of Gingee, Kanara, Mysore, Travancore, Madurai, Marava, Tanjore (today's Thanjavur), by the middle of the century spreading northwards toward Golkonda, and including of course Pondicherry (today's Puducherry), the headquarters of the French missions and the French empire in India.

2 See Chapter 8 of Quentin Garreau, "Fuir la mission: L’abbé Dubois, un missionaire français au service des britanniques en Inde" (Master's thesis, École des hautes études en sciences sociales, 2011), 129-55. 
Mours et coutumes to the European public without the message itself suffering discredit. $^{3}$

That the first treatise of Indology conveyed a Jesuit message seems to contradict the primacy of the Enlightenment as the birthplace of anthropology, an assumption that remains dominant in histories of the field, ${ }^{4}$ and one that goes back at least to Michèle Duchet's Anthropologie et histoire au siècle des Lumières (Anthropology and history during the century of lights) (1971). This classic book argued that anthropological discourse was ultimately aimed at European self-understanding, and that it constituted an "internal transformation of the sensualist system" that united "in one discourse the history of the feeling and thinking individual, and that of the species, biological reality and collective being, the history of man and that of human societies." ${ }^{n}$ The systems of well-known philosophers like Buffon, Rousseau, Voltaire, Diderot, and Helvetius were the best representatives of this sensualist transformation according to Duchet, who deliberately "set aside" authors like Jean-François Lafitau (1681-1746), Charles de Brosses (1709-77), Cornelius de Pauw (1739-99), and Anne Robert Jacques Turgot (1727-81), and texts like l'Histoire générale des voyages (General history of voyages) (1745-59) and the Lettres édifiantes et curieuses, écrites des missions étrangères (Edifying and curious letters, written from the foreign missions) (1703-73) in search of more "rigorous" discursive manifestations of early anthropology. ${ }^{6}$ Though Murr concentrated on one of the minora that Duchet had laid by, she actually discussed Moeurs et coutumes des Indiens as Duchet might have done, that is, as a pure product of mainstream enlightened philosophy, and concretely as Cœurdoux's attempt to counter Voltaire by holding India up as a mirror for Europe.

Problematically, however, thinking about early field anthropology strictly as a consequence of the mainstream Enlightenment and only as an attempt at European self-reflection effectively excludes the theoretical and methodological contributions made to the field by the cultures described (a fact that remains to this day astoundingly unstudied), and by the not necessarily enlightened worldviews of those most directly concerned, that is, those scholars who actually created empirical anthropology in what we today might call "the

3 On Cœurdoux's authoring of Mours et coutumes and Desvaulx's probable motivations, see Sylvia Murr, L'Indologie du père Coeurdoux, in L'Inde philosophique entre Bossuet et Voltaire, 2 vols. (Paris: École française d'Extrême-Orient, 1987), 2.

4 See, most recently, Larry Wolff and Marco Cipolloni, eds., The Anthropology of the Enlightenment (Stanford: Stanford University Press, 2007).

5 Duchet, Anthropologie et histoire au siècle des Lumières (Paris: Albin Michel, 1995; 1971), 21.

6 Duchet, Anthropologie et histoire, 20. 
field," on the basis of personal observation, lived experience, and the reading of non-European sources. At least in the case of the Catholic missionaries, attending to their larger worldviews and their interactions with the surrounding culture leads to the discovery that early anthropology aligned more readily with conservative enlightened rather than with mainstream enlightened sensibilities. Missionaries' lives also suggest the limits of their connection with enlightened views of any kind. Cœurdoux himself arrived in South India in 1732, died in Pondicherry in 1779, and never returned to France. He lived and worked in India for over half of his life, baptized and catechized thousands of Tamils, served as superior of the Karnataka mission, and took up the role of spiritual director of Pondicherry's four thousand Tamil Catholics (1744-51). In 1748, he also founded a Carmelite convent for Tamil girls as a testament to his commitment to the contemplative life-hardly a man, one would think, convinced by the idea that human fulfilment depends primarily on reason.

As an Indianist, Cœurdoux was the disciple of the Jesuit philologist and Sanskrit poet Jean Calmette (1692-1740), the man who, having attended the "Brahmins' famous universities,"7 attained such skill in composing shlokas or Sanskrit verses in praise of the Divine that the Brahmins bestowed upon him the extremely rare privilege of initiating him into Hinduism (an honor that almost certainly remained unknown to Calmette's superiors in Rome). It was Calmette who gained a knowledge of Sanskrit sufficient to become the first European to find and gather the four Vedas - which the Brahmins had guarded jealously for millennia, and been particularly careful to secrete from the Jesuits - thus ending the Society's century-long quest for these sacred texts. And it was most likely Calmette who composed the Ezour Vedam (1778) or Veda of Jesus, the most famous forgery in the history of Orientalism that fooled even Voltaire by presenting Catholic theology as a collection of ancient Vedic verses. ${ }^{8}$

Calmette and Courdoux, though, were themselves heirs to a rich Jesuit Indianist tradition that went back to the sixteenth century. The present essay is the first reading to date of Mours et coutumes in this context, and in the

7 Lettres édifiantes et curieuses, écrites des missions étrangères, 26 vols. (Paris: J.-G. Mérigot Le Jeune, $1780-1783$ ), 1:6*. This was one of two editions that were available to me during the composition of this essay, one of which is incomplete. The other one is the original, $1703-76$ Nicolas Leclerc edition (34 vols.). The Mérigot Le Jeune edition here referenced is indicated with "**" in the footnotes.

8 On Calmette, see Urs App, The Birth of Orientalism (Philadelphia: University of Pennsylvania Press, 2010), 374-78 and 401. 
context of the Indian sacred culture that itself shaped early Jesuit Indological perspectives. The dual goal of this approach is to understand, first, how various influences, both thematic and methodological, converged to make the text, and second, how the Jesuit Indianist tradition evolved over the centuries in response to political conflict, theological controversy, and the local cultural milieu in order to yield (ironically once the Society of Jesus had been dissolved and the mission project was over) a new empirical discipline. Including such early first-hand descriptions as Antonio Monserrate's (1536-160o) Comentario (Commentary) (completed in 1590) and Giovanni Antonio Rubino's (1578-1643) Relazione d'alchune cose principali del regno di Bisnagà (Report on some principal things of the kingdom of Vijayanagara) (1608); encyclopedic attempts at religious description, notably Jacome Fenicio's (1558-1632) Livro da seita dos indios orientais (Book on the sect of the oriental Indians) (1609); poetic works in the indigenous languages, such as Thomas Stephens's (1549-1619) Kristapurāna (Purana of Christ) (1616) and Constanzo Beschi's (1680-1747) Thembavani (Unfading garland) (date unknown); philological treatises on Indian religious texts like Roberto de' Nobili's (1577-1656) Informatio de quibusdam moribus nationis indicae (Report on some mores of the Indian nation) (1613); and the famed epistolary collection of the Age of Enlightenment, the Lettres édifiantes et curieuses, the Jesuit Indianist tradition provided a wealth of genres, methods, approaches and knowledge about India that Courdoux's founding opus either modified, incorporated, or innovated upon by antithesis.

Flowing from the pens of veteran missionaries inspired by Catholicism, versed in the Hindu scriptures, and familiar with the smallest details of Indian daily life, the story of early Indology is very different from the story of early anthropology told by the Enlightenment's great works. Instead of sensualism, this story teaches devotion; rather than apply reason, it discerns spirituality; in the place of egalitarian utopias, it perceives a natural, providential order emerging from sacred history; and in lieu of organizing knowledge according to mental constructs, it seeks the precise description that the monastic orders of early modern Europe took to its height before classical erudition's displacement by the Enlightenment's worldly literature. ${ }^{9}$ Not that Moeurs et coutumes is a mere exercise in retrospection. Its systematic description is dictated by new approaches to the sources, to temporality and narrativity that together comprise nascent ethnography's methodological characteristics.

The composition of classics of Tamil, Telugu, Konkani, and Marathi, in poetry and in prose, was one of the side products of the Jesuit missionary project in

9 Blandine Barret-Kriegel, "La défaite de l'érudition," in Les historiens et la monarchie, 4 vols.

(Paris: Presses Universitaires de France, 1988), 2. 
India, as were the first European ventures into Sanskrit studies, the realization of the parentage between Indian and European languages and, of course, the founding of Indology that Mours et coutumes itself represented. All of these endeavors implied a focus on local languages and national characters that signaled the birth not just of anthropology —in Duchet's sense of the uniting of "the history of man and [...] of human societies"—but more specifically of ethnography - the description of the customs and habits of different peoples that to this day remains the dominant branch of anthropology in France, the homeland of the Jesuits who were founders of ethnography. Like previous Jesuit Indianism, Moeurs et coutumes was also ethnographic in character, while its all-pervading concern with the Indian character is in turn typical of the anticipations of nationalism that Dale Van Kley has associated with the Society of Jesus in the eighteenth century..$^{10}$ This essay examines Mours et coutumes in the context of the Jesuit Indianist tradition in order to argue that insofar as the text relates to the Enlightenment, it is through a methodology that aligns it with enlightened conservatism. The related claim is that the study of early ethnography and field anthropology enhances our understanding not only of anthropology's non-European origins, but also of the Enlightenment's varieties and of the non-European ancestry of social and political conservatism.

Although the title of Mours et coutumes des Indiens refers to Indians in general, the text actually concentrates on the Brahmin caste. Murr argues that by focusing on the Brahmins Cœurdoux was reworking De opene deure tot het verbogen heydendom (The open door to hidden heathendom) (1651), a study of Hinduism by the Dutch clergyman Abraham Roger (1609-49) that identified Brahmin worship and religious customs as the key to Indian religion. Cœurdoux mentioned in a letter to the famed Orientalist Abraham Hyacinthe AnquetilDuperron (1731-1805) that De opene deure was full of errors, and Murr believes that Mours et coutumes was an attempt to provide an extended and corrected version of this respected work that would convey Jesuit apologetics by positing the Brahmin life as symbolic of the whole of Indian social and religious life. ${ }^{11}$ Thus where Roger discussed only the first two traditional stages or ashramas of Brahmin life-brahmacharya or the student years that Brahmin boys spent

10 See Dale Van Kley, "Religion in the Age of Patriot Reform," Journal of Modern History 80, no. 2 (2008): 252-95.

11 Murr, Indologie du père Couurdoux, 72-74. 
under a guru's guidance, and grihasta or the married and householder stageCœurdoux also covered the two later, spiritual stages: vanaprasta, an ashrama described in Vedic literature when, after a couple's children had married, the couple retired to the forest to do spiritual exercises; and sannyas, the ascetic or celibate stage which traditionally followed vanaprasta but which could also be entered into by a young Brahmin directly after brahmacharya. This sannyas stage was wholly devoted to spiritual exercises and the seeking of mukti or spiritual liberation - what is more popularly known by the Buddhist term nirvana..$^{12}$ Cœurdoux's addition of these last two spiritual stages can be seen as an application to the Brahmin ashrama of the eighteenth-century encyclopedic drive to describe things in their totality rather than in their parts. Yet it is even more consistent with his Catholicism and especially his interest in contemplation. For although Cœurdoux generally had few good things to say about Hinduism, he also harbored sympathy for Indian spiritual asceticism, writing that "most of the terms" that Indian penitents use to describe spiritual experience "would not be rejected by our mystical doctors." ${ }^{13}$ The statement suggests that he believed Hindu mysticism to be at least partly genuine. His founding of a convent for its part confirms that, like a good Catholic and in agreement with Hindus, he revered mystical experience as the highest goal of human life.

Cœurdoux focused on the Brahmins partly because they had been the central object of Jesuit Indianist attention ever since Francis Xavier (1506-52), the co-founder of the Society of Jesus and the first Jesuit visitor to India, first began reflecting on Indian culture and religion after conversing with a Brahmin. ${ }^{14}$ As the learned and the sacerdotal caste, the Brahmins were the Jesuits' natural rivals, persecutors, and interlocutors, but they were even more importantly the objects of Jesuit emulation ever since, shortly after disembarking in Goa in 1605, the Italian Jesuit Roberto de' Nobili $\left(1577^{-1656)}\right.$ had realized that the key

12 Strictly speaking, and given the Hindu critiques of nirvana that have traversed the millennia, mukti and nirvana cannot be taken to be exactly synonymous terms. In Hindu and yogic mukti, everything is the Self as unified consciousness, whereas in nirvana, there is neither Self nor consciousness. On a very grossly general level, this divergence may be taken to hinge on the difficulties of grasping the Buddhist concept of emptiness. For an introductory and historically contextualized discussion of the debate, see Chapter 5 of Sue Hamilton, Indian Philosophy: A Very Short Introduction (Oxford: Oxford University Press, 2001).

13 Cœurdoux, "Mœurs et coutumes des Indiens," in Murr, Indologie du père Coeurdoux, 1:123.

14 See Francis Xavier, Letter to his companions at Rome, January 15, 1544, Cartas y escritos de san Francisco Javier: Única publicación castellana completa según la edición crítica de "Monumenta Historica Soc. Iesu" (1944-45), ed. Félix Zubillaga, S.J., $3^{\text {rd }}$ ed. (Madrid: La Editorial Católica, 1979), 112-13. 
to converting India's upper castes was for the Jesuits to pass themselves off as "Brahmins from the North," keepers of the true Vedas that had been corrupted in the South. ${ }^{15}$ Nobili's further decision to adopt the sannyasi or Brahmin ascetic lifestyle was hugely successful. It earned him a public respect manifested by his adoption of the spiritual name Tattuva Bodhakar, or "Guru of Reality." And it enabled him to make enough conversions among Brahmins and Rajas as to have to build a new church to accommodate his new community. Given the success of the approach it is little wonder that it should have been adopted by all later Jesuits in India including Courdoux. ${ }^{16}$ Beyond observing the Brahmins, then, the Jesuits strove for centuries to be and to become them outwardly. It was therefore natural that - besides his scholarly dissatisfaction with Roger's masterwork-Cœurdoux should focus on the caste whose conversion his order most desired, and whose lifestyle served as a model for his own and his companions' - if only in the world of appearances.

\section{Approaching the Sources}

Gaining insight into Brahmin life could be done in various ways. Protestant Indologists like Roger and the Pietist missionaries of the Danish colony of Tranquebar gathered information about India by asking Indian scholars questions about Hindu beliefs and practices. Roger wrote De opene deure by interrogating a pandit, ${ }^{17}$ while the Pietist missionaries asked Hindu scholars their opinions on Europeans, Christianity, and the Danish government of Tranquebar-questions

15 On Nobili, see Ines Županov, Missionary Tropics: The Catholic Frontier in India $\left(16^{\text {th }}-17^{\text {th }}\right.$ Centuries) (Ann Arbor: University of Michigan Press, 2005) and Županov, Disputed Mission:Jesuit Experiments and Brahmanical Knowledge in Seventeenth-Century India, Oxford India Paperbacks (Oxford: Oxford University Press, 2001; 1999).

16 The life of the sadhus sannyasi that Nobili had chosen for himself gave him the highest, Brahmin status, but it had the double disadvantage of requiring an asceticism that surpassed the inner and physical strength of most Jesuits, and of making interaction with the lower castes impossible, as such contact would have been thought to pollute the sannyasi. Nobili hence decided that it was best if his successors became pandarams, ascetes who led a less rigorous life, needed fewer intellectual skills, and could transact with both higher and lower castes. The move helped to make Nobili's accommodatio a far bigger phenomenon: most of the Jesuits who wrote the Indian Lettres édifiantes lived as pandarams. See Stephen Neill, A History of Christianity in India: The Beginnings to 1707 (Cambridge: Cambridge University Press, 2004).

17 A Brahmin scholar, especially one who has learned the Vedas and can sing them during rituals. 
to which the scholars responded in ninety-nine letters richly laden with information. ${ }^{18}$ The resulting social description, which lent Indians (even if it was only elite Indians) their own voices, was unknown among the Jesuits. Although the latter also used informants, they drew on Catholic theology and scholarly prescriptions to interpret their informants' accounts and weave them together with their own observations, and with the evidence drawn from Indian classical texts, in order to compose authoritative and objectivist descriptions.

Cœurdoux drew on three main sources when describing the four ashramas of Brahmin life: his own observations of Indian daily life and practices, classical and religious Hindu literature, and the ritual manual kept by the Purohit Brahmins or masters of ceremonies. He assigned no differential value to the information these disparate sources provided, and treated the Indian reality to which they referred as timeless and holistic. His synchronic perspective is easy to dismiss as stereotypically Orientalist, yet the view that Hinduism lacks historical sensibilities remains to this day a cliché in the field. ${ }^{19}$ Even recent attempts to question this cliché are obliged to collate fragmentary evidence from epigraphic, artistic, and even mythological materials, and to invoke "a conspiracy of negative forces" 20 that include invasions, the tropical climate, and the lack of autonomy of historical consciousness as explanations for the absence of both manuscript and historiographical traditions. In the humble opinion of this non-specialist, arguments of this kind, which seem to abound in present-day Indianist scholarship, seem more motivated by the desire to discredit Orientalism and cut India on the pattern of modern Europe-itself an unconsciously Eurocentrist aim - than they are to describe Hinduism, to quote Leopold von Ranke (1795-1886), wie es eigentlich gewesen (as it actually was). ${ }^{21}$ The principle central to Upanishadic thought that neither the past nor the future exist, and that the path of pragni or awareness is followed by focusing

18 Gérard Colas, "Curiosité, science et intéraction pédagogique; la mission française jésuite et la mission piétiste de Halle en Inde du sud au XvıII ${ }^{\mathrm{e}}$ siècle," Études épistémè: Revue

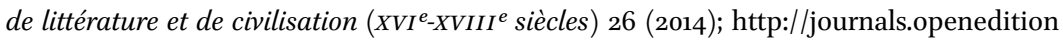
.org/episteme/335 (accessed July 24, 2019). For a more skeptical account of the reciprocity of Protestant missionary correspondence with learned Hindus, see Joan-Pau Rubiés, "Tamil Voices in the Lutheran Mission of South India (1705-14)," Journal of Early Modern History 19 (2015): 71-81.

19 See Avind Sharma, "Did the Hindus Lack a Sense of History?," Numen 2 (2003): 190-227, here 190.

20 Sharma, "Did the Hindus," 212.

21 See Ranke, "Preface: Histories of the Latin and Germanic Nations from 1494-1514," in Fritz Stern, ed., The Varieties of History: From Voltaire to the Present (New York: Vintage Books, 1973), 57 . 
one's mind, emotions, and energies in the present moment may be related to Hinduism's comparative lack of interest in history as a discipline encouraging attachment to the past— that is, to what does not exist—and thereby holding one in the world of maya or illusion and away from the truth attained through self-knowledge. Be that as it may, even the genealogical records kept mostly by kings, which form the core of historical tradition in India, ${ }^{22}$ were not accessible to the Jesuits in the eighteenth century, a fact which helps explain why a synchronic perspective that juxtaposed ancient sources with presentday observations may have been natural to Courdoux, and probably even the only option available to him. This would certainly make clear why he has no problem finding ancient explanations for present-day phenomena, notably ascribing his observation that the Indian women of his day "are reduced to the state of the most vile slaves"23 to the prescriptions for feminine living made in the Padma Purana, one of the eighteen major Puranas, which scholars estimate was written anywhere from the third to the fourteenth centuries of our era-that is, at least four centuries before Courdoux's time. ${ }^{24}$

A synchronic approach to time coexists in Moeurs et coutumes with a cyclical temporality expressed through the founding primacy ascribed to ritual at every stage of Brahmin life. Thus, the description of brahmacharya ashrama comprises mostly a minute description of Upanayana - the ceremony whereby a little Brahmin boy is invested with the sacred triple thread that symbolizes his caste and marks the beginning of his studies under a guru. Upanayana literally means "leading or drawing toward one's self,"25 and refers to a guru's drawing of a child toward his true self. ${ }^{26}$ This interiorizing aspect, however, seems to have been lost on Courdoux, who as a reason-oriented European of the Age of Enlightenment - and as an intellectual descendant of Nobili, who had assuaged his European superiors by emptying Hinduism of spirituality-saw the ritual primarily as conferring "the right to all the Sciences."27 The lack of awareness, whether deliberate or unconscious, of interiorizing dimensions resulted in a depiction of ritual as the purely exterior and socializing foundation

22 Romila Thapar, Ancient Indian Social History: Some Interpretations (New Delhi: Orient Longman, 1978), 278.

23 Cœurdoux, Mours et coutumes, 96.

24 See Sharda Arya, Religion and Philosophy in the Padma-Purana (Delhi: Nag Publishers, 1988), xx and lxii.

25 Dictionary for Spoken Sanskrit, http://spokensanskrit.org (accessed July 23, 2019).

26 The "true self" sought here can be thought of interchangeably as the child's or the guru's: since in Hinduism Brahman or ultimate Reality is a single coherent Self, no difference exists between the child's and the guru's self.

27 Cœurdoux, Mours et coutumes, 31. 
of Brahmin life. Thus, whether describing brahmacharya or sannyas, Courdoux focused mostly on the ceremonies that consecrate these states, and-in the case of sannyas - on the death rituals that terminate it.

Because the married state of grihasta was far more common, Cœurdoux could combine his minute description of the ceremony of marriage with his own observations of ordinary married life. These last emphasized the lack of friendship between husband and wife in traditional Indian marriage, and the plight of Indian wives and widows, a recurrent theme in Moeurs et coutumes. ${ }^{28}$ As for vanaprasta, because it was a historical stage, Courdoux again turned to the Padma Purana, from which he gathered that the vanaprastas were "all infatuated with the virtue of MANTRAM and quite devoted to the practice of Sacrifices, which constituted even their great occupation."29 In combining contemporary eyewitness accounts with centuries-old literary evidence, Courdoux adopted history's factual erudition while discarding history's linear temporality. In doing this, he announced—probably quite inadvertently—the dawn of a new science that combined systematic cultural description with cyclical and synchronic notions of time.

\section{$3 \quad$ Extracting Facts, Excluding Stories}

Cœurdoux's method of extracting facts from diverse sources to reconstruct a unitary and atemporal social and cultural reality is the scientific consummation of the radical break that French Jesuits made with previous Jesuit Indianism when they took the reins of the Asia missions from Portuguese and Italian Jesuits in the late seventeenth century. The pioneer of the literary tradition that characterized Jesuit Indianism during the first centuries of the missions was Thomas Stephens (1549-1619) - the third Englishman to ever set foot in India, and the first to have arrived there through the Cape of Good Hope. His project began as a response to a local tragedy. In 1583, as the Portuguese empire conducted violent Christianization campaigns in the region of Goa, five Jesuits and fifteen Christian laymen were massacred by kshatriyas or members of the warrior caste in the village of Cuncolim. The Portuguese government responded by killing fifteen or sixteen kshatriyas (the exact number is uncertain as one of them reportedly escaped execution by jumping into the Assolna

28 Courdoux, Mours et coutumes, 87-99.

29 Cœurdoux, Mours et coutumes, 126. 
River through a toilet hole), ${ }^{30}$ but Stephens, who was responsible for burying the Christian dead-including the Jesuit Pietro Berno (1552-83), his friend from novitiate days - set out to create a culture of dialogue with Hindus that emphasized love over authority, pacifism over violence, and apostolic zeal over the forced conversions that had characterized Christianization in Portuguese India since at least the 1560 .

Creating this culture required mastering the local languages. Stephens is remembered to this day for his contribution to the development of Konkani in the Roman script, which he codified in his Arte da lingoa canarim (Art of the Canarim language) (1640), the first grammar of Konkani ever published, which made of Konkani one of the first modern Indian languages to possess a codified grammar. ${ }^{31}$ Also, at the suggestion of one of his high-caste converts, and after studying Marathi-the language of Goa's cultivated castes, and of the great poets of Maharashtra's medieval Santha literature, Jnaneshvar (127596), Namdev (c.1270-c.1350), and Eknath (1535-99)-Stephens composed the Kristapurāna (Purana of Christ) (1616), an epic poem in eleven thousand stanzas that tells the Christian story from the creation of the world to the ascension of Jesus. This work, which has seen eight editions through the centuries, three of them in seventeenth-century Goa, ${ }^{32}$ transformed Stephens into one of the Subcontinent's most celebrated poets. In 1913, Henri Hosten affirmed of the Kristapurāna that "this work is so agreeable that not only do the Christians derive much profit from it, but even the gentoos [gentiles] take pride on speaking of it."33 In 1957, the Marathi daily newspaper Sakāla compared it to "the monumental Purānas of the famous poets like Sridhar and Muketeshvar," and in his 1961 doctoral dissertation on the Kristapurāna, S. G. Malshe lauded "the originality and pristine beauty of the epic work of Father Stephens." 34 The magnum opus was not only read in private but also recited

30 See "Cuncolim Revolt," https://www.revolvy.com/page/Cuncolim-revolt?cr=1 (accessed May 31, 2019).

31 Mariano Saldanha, "História de gramática concani," Bulletin of the School of Oriental Studies 8 (1935-37): 715-35, here 715 .

$32 \quad 1616,1649$, and 1654.

33 See Henri Hosten, S.J., "Earliest Jesuit Printing in India: From the Spanish of the Rev. Cecelio Gomez Rodeles, S.J., Journal and Proceedings of the Asiatic Society of Bengal, New Series 9 (1913): 149-68, here 162n, quoted in Nelson Falcao, Kristapurāṇa: A ChristianHindu Encounter (Pune/Anand: Snehasadan Institute for the Study of Religion/Gujarat Sahitya Prakash, 2003), 12.

34 S. G. Malshe, Stīphansacyā Krīstapurānācā Bhāsika āni Vāngamaȳ̄na Abhysa, Unpublished Summary of the Doctoral Thesis (Mumbai University, 1961), 36, quoted in Falcao, Kristapurāṇa, 17. 
in churches during liturgical celebrations until the 1930s, spawning admiring emulations that included a Purana on St. Peter by the French Jesuit Étienne de La Croix (1579-1643) and another on St. Anthony by the Portuguese explorer António de Saldanha (dates unknown).

The Kristapurāna must also have influenced the Jesuit and Tuscan aristocrat Roberto de' Nobili of Malabar rites fame, whom Stephens probably took on a missionary tour of Goa when the Italian first arrived in India in $1605 .{ }^{35}$ Like his mentor, Nobili learned the local languages but broke new ground by adding Sanskrit to his repertoire. His prose writings in Tamil, which practiced philological exegesis upon South Indian religious literature as a primary means of understanding India, made key contributions to the development of the language. ${ }^{36}$ Nobili also became a celebrated poet, composing Kirttanas or sacred hymns that are sung to this day by Tamils.

Nobili's fellow Italian Constanzo Beschi (1680-1742) brought Jesuit literary Indianism to a brilliant close by translating into Latin the classic Tirukkural (Sacred verses) (c.450-50o) of the great poet Thiruvalluvar (dates unknown), and drawing inspiration from it to compose his own Tamil masterpiece, the Thembavani (Unfading garland) (date unknown), which used Tamil literary devices to tell in verse the life of St. Joseph from his birth to his heavenly coronation. In 1981, the Fifth World Tamil Congress erected Beschi's statue on the Chennai beachwalk in recognition of his contribution to Tamil language and literature. ${ }^{37}$

Of this great literary tradition the Lettres édifiantes et curieuses, which formed the core of eighteenth-century French Jesuit Indianism and to which Cœurdoux himself contributed, give not a single sign. The French Jesuits who directed India's missions in the eighteenth century identified as Nobili's heirs insofar as they adopted the ascetic lifestyle that he had been the first to lead, and that enabled them to earn the Indians' respect and effect huge numbers of conversions to Christianity. But the admiration for, and deep understanding of, Indian literature that had motivated the integrative efforts of Stephens, Nobili, and Beschi vanished from the worldview of the Jesuits of the Age of Enlightenment. The only admiring passage on classical Hindu literature contained in the Lettres is by Father Jean-François Pons $(1698-1752)$ in praise of Sanskrit

35 See Augustine Saulière, His Star in the East, ed. S. Rajamanickam (Madras and Anand, 1995), 22.

36 On Stephens, see Francis X. Clooney, Introduction to Roberto de Nobili, Preaching Wisdom to the Wise: Three Treatises (St. Louis, MO: Institute of Jesuit Sources, 200o).

37 “Magnificant[sic] Marina,"August31,2017,inTheMadras,https://themadras.in/magnificant -marina/ (accessed July 2019). 
grammar. "The Grammar of the Brahmins," he wrote, "can be placed in the rung of the most beautiful sciences; never were Analytics and Synthesis more happily employed than in their grammatical works of the Samskret or Samskrutan language."38 And he exulted: "It is amazing that the human mind has been able to attain the perfection of art, that bursts forth in these Grammars: in them, the Authors have reduced by Analysis the richest language in the world, to a small number of primitive elements." 39 The beauty of Pons's delight, though, was that of language rather than literature, of analysis rather than imagination, of grammars and not of moral or mythological works. It was an admiration understandable in an heir of Descartes, for whom poetry was the unreliable antithesis of analysis, and to whom rules, especially of language, were so important-as exemplified by the Grammaire de Port-Royal (1660), which no educated eighteenth-century Frenchman could ignore. ${ }^{40}$ Cœurdoux himself was no fan of the Sacred verses. The poem that inspired Beschi's masterpiece was in his eyes but "a collection of Sentences expressed in a manner so concise, that they are Often unintelligible to [...] Indian Scholars" and fall far short of being "as beautiful in themselves as they seem to Indians." ${ }^{41}$ The lack of aesthetic engagement denoted by these comments discloses an intellectual world where it was fact and systematic analysis, rather than poetry and imagination, that conveyed truth and possessed beauty.

Derived dually from Descartes and Locke ${ }^{42}$-rather than from Locke and Bacon, as in the Encyclopédie - the epistemology that guided Cœurdoux was the empirical and methodical one of enlightened conservatism. Because the Encyclopédie identified the imagination as its cheval de bataille - and because Rousseau deployed it in his philosophy as a major epistemological tool - the more traditionally minded Christian enlighteners whose historical religion had always encouraged erudition, championed the fact as the only reasonable vehicle to truth. ${ }^{43}$ This erudite mentality differed from the Encyclopédie's empiricism in that it saw truth emerging not from human reason's exercise

$38 \quad$ Lettres édifiantes, $26: 222$.

39 Lettres édifiantes, 26:224.

$40 \quad$ See Paul Bové, "Philology and Poetry: The Case against Descartes," Law and Literature 21, no. 2 (2009): 149-68.

41 Cœurdoux, Mours et coutumes, 174.

42 On the eighteenth-century French Jesuits' reworking of Descartes and Locke, see Jeffrey D. Burson, The Rise and Fall of Theological Enlightenment:Jean-Martin de Prades and Ideological Polarization in Eighteenth-Century France (Notre Dame: Notre Dame University Press, 2010).

43 On the Catholic clergy's epistemological defense of facts, see William R. Everdell, Christian Apologetics in France, 1730-179o: The Roots of Romantic Religion (Lewinston: Edwin Mellen, 
upon facts, but from the divine intent that facts themselves disclosed. It was an erudition characteristic of the Jesuits and more widely of the learned clergy, themselves precursors of the epistemology of early religious conservatives and precursors of sociology like Joseph de Maistre (1753-1821).44

Dwelling upon facts rather than deploying reasoned arguments did not suffice, however. It was preferable as well that the facts presented should not themselves be reasoned products of the human mind, and especially that they should lack an intellectual or high cultural character. Coeurdoux had no interest in the Hindu gods and their myths. The "Indian fables" he had rather tell were drawn from the oral and popular wisdom repository, like the comical moral tales he himself retold, "The Four Deaf Men" and "The Four Original Brahmins."45 It was a way of both privileging fact over imagination, and of emphasizing ordinary Indian life over Hindu high culture.

Compare the first Jesuit text devoted to Indian religion, composed by the Capuan astronomer and expert in Malayalam, Jacome [Jacobo] Fenicio (15581632 ). While residing at the court of the Zamorin of Calicut in the year 1600, Fenicio had consulted a wide variety of Hindu religious texts, which he synthesized in his Livro da seita dos indios orientais (Book of the sect of the oriental Indians) (16o9). The Indologist Jarl Charpentier (1884-1935) judged the Livro a "priceless manuscript" that should have earned its author "eternal fame" if only for the Indological materials it presented. ${ }^{46}$ Indeed, this summa was the first thorough, detailed, and systematic European description of the myths and cults of the Hindu trimurti (the trinity of Shiva, Vishnu, and Brahma) arranged in such a way that the many stories pertaining to each god comprised a chronological account. The book's conclusion for its part described briefly the rituals of each cult. Like a conscientious missionary, of course, Fenicio made it a point to ridicule the gods, whom he portrayed as concupiscent creatures as far as accuracy would allow. Still, he deemed their stories crucial to understanding Indian culture. Not Courdoux. More interested in the mentality and daily living of the whole population he sought to convert, the Frenchman excluded

1987), 109-43 and Robert R. [Roswell] Palmer, Catholics and Unbelievers in EighteenthCentury France (Princeton: Princeton University Press, 1939).

44 On Maistre's divinization of the fact and concomitant discarding of fables, see Carolina Armenteros, The French Idea of History: Joseph de Maistre and his Heirs, 1794-1854 (Ithaca, NY: Cornell University Press, 2011), 45-49. On the development of the idea of the fact among nineteenth-century Catholic thinkers, see Chapter 6 of the same work.

45 See Chapter XLviI of Cœurdoux, Moeurs et coutumes.

46 Jacobo [Jacome] Fenicio, The Livro da seita dos indios orientais (Brit. Mus. Ms. Sloane 1820) of Father Jacobo Fenicio, S.J., ed. Jarl Charpentier (Uppsala: Almquist and Wiksells Boktyckeri-A.-B., 1933), lxxii. 
mythography and religious literature as the incomprehensible preserve of a corrupt Brahmin elite. That was the moral, Catholic reason. The pragmatic, enlightened one was the Jesuit need to gain legitimacy among a European public enamored of reason and repelled by what it considered to be irrational behavior and superstitious productions. Hence Mours et coutumes' lamentations on India's "excesses," which ranged from "the most outrageous praises" that characterized its common compliments ${ }^{47}$ to the "vulgar taste" and "deranged imagination" of "the most insensate [poets] in the universe."48

Excluding mythography and reducing literature to a source of cultural and moral facts about ordinary life also contained a creative possibility because it allowed Moeurs et coutumes - the very text from which mythography had been excluded - to itself acquire mythical qualities. As the account of a society at once past and present that was emancipated from the vicissitudes of linear time, Mours et coutumes possessed myth's foundational explanatory power. In its pages ritual practices and ordinary habits took on the aura of an eternal return that generated social life unfailingly in consonance with the cycles of human time, represented by samssāra, that are so central to Indian philosophy. Simultaneously, the text's totalizing snapshot of a stable and unchanging civilization, well-ordered to the point of illusion, lent its systematic social description the status of scientific truth. Fenicio, Stephens, and Beschi had all tried to understand India through its founding stories, and Stephens and Beschi had tried to communicate with Indians by crafting Christian versions of these stories. Cœurdoux had rendered India fully understandable by eclipsing narrative in order to give birth to a discourse that focused on a symbolic portion of Indian reality - the Brahmin life, itself fully understandable through Brahmin rituals - in order to offer a total, factual, "real" rather than symbolic explanation of that reality. The end of narrative in turn meant the conflation of quite varied information. Courdoux drew on ancient and modern sources, written texts and lived experience, and extracted from them facts of equal truth value which he liberally combined as if the differing character of their origins were of no consequence. After all, no temporal distances marked the differences between them.

The result was a new science that devalorized literature; valorized first-hand observation; adopted a synchronic approach; attempted a systematic description of the social whole; and selected a symbolic subject through which that whole could be known.

47 Cœurdoux, Mours et coutumes, 164.

48 Cœurdoux, Mours et coutumes, 177. 
How significant the strategic isolation and systematizing of the spiritual fact symbolized by the Brahmin life was to the emergence of a new discursive possibility becomes clear when comparing Cœurdoux's descriptive effort with the first-hand and detailed descriptions of India the Jesuits had been producing since the 1580s, when the Spaniard Antonio Monserrate (1536-16oo) wrote his Comentario, ${ }^{49}$ a description of the court of the Mughal emperor Akbar (r.1556-1605) based on the diary that Monserrate kept daily during his nearly two years of residence in the palace complex at Fatehpur Sikri. The Spaniard noted conscientiously everything he witnessed-from the emperor's religious interests to his involvement with architecture to the training of the imperial army's elephants. The Italian Jesuit Antonio Rubino (1578-1643) —a resident at the court of Venkatapati Raya or Venkata II (r. c.1585-1614), emperor of Vijayanagara-followed in Monserrate's footsteps with his own Relazione d'alchune cose principali del regno di Bisnagà (Report on some principal things of the kingdom of Vijayanagara) (1608). Impressed by the enormous wealth, and by the great architectural and administrative achievements of the thenmighty empire of Vijayanagara, Rubino described in detail the treasures of the king and Brahmins, the empire's principal temples, the main gods, the caste system, the empire's social and religious practices, and the four mythological ages or yugas into which Hinduism divided the world's time. Though very different from Monserrate's description, Rubino's Report nevertheless resembled it in that it mixed the description of spiritual and material subjects. More interested, however, in the more striking material ones, what little attention the text paid to Hinduism was devoted mainly to condemning it as infernal. ${ }^{50}$

Courdoux, by contrast, not only subordinates the material realm to a spiritual realm far more neutrally conceived, but he also concentrates his discussion on social practices and performances rather than on beliefs, stories, and other undertakings of the mind, the sciences included. At the same time, his spiritual realm is actually quite material in that it is concerned not with interior experience, but with external behavior and the representation of higher dimensions. His rituals and ceremonies also function more as objective,

49 The Commentary of Father Monserrate, S.J., on His Journey to the Court of Akbar, ed. S. N. Banerjee and trans. J. S. [John Somervell] Hoyland (London: Oxford University Press, 1922).

5o See Joan-Pau Rubiés, “The Jesuit Discovery of Hinduism: Antonio Rubino's Account of the History and Religion of Vijayanagara (1608)," Archiv für Religionsgeschichte 3, no. 1 (2001): $210-56$. 
providential dictates than as Indian inventions. They are the keepers of order as the Brahmins conceived them, and as Catholicism taught that they should be. Brahmanism, in fact, seems Christianity's mirror. Under Courdoux's pen, the Brahmins, who watch each other constantly when assembled, become like a "community of regular monks," ${ }^{1}$ deplorable from a European point of view for their ultimate moral emptiness, yet admirable also by comparison with Europe for their ability to keep up appearances and defer to the spiritual order. Cœurdoux thus suggests what a utopia Europe could be if it were to emulate India's spiritual priorities and policing of appearances, even as he evokes the utopia that India could be if its morally empty culture were infused with the spirit of the "true religion."

Cœurdoux understood, then, that unlike Christianity, Hinduism is not based on morality. This was an important realization because it provided a solution, acceptable by enlightened standards, to a problem that had haunted the Jesuits for centuries: what, precisely, the ontological status of Hinduism might be. Jesuit opinions on this matter had seesawed between fears of demonism and assurances of spiritual emptiness, from Fenicio's depiction of the gods as depraved figures to the respect for Hinduism implied by Stephens's application, in the Kristapurāna, of the four hundred names of Vishnu to Christ and God the Father: Vaikuntharaja (King of Heaven), Vaikunthanatha (Lord or Master of Heaven), Vaikunthanayaka (Chief or Head of Heaven), among others. ${ }^{52}$ Neither respectful nor particularly denunciatory (in comparison with his predecessors), Cœurdoux treated Hinduism as a collection of rituals that, ridiculous though they might seem to Europeans, still functioned to organize efficiently a highly complex civilization.

This was at once an innovation upon, and an adaptation of, the strategy that Nobili had developed to make sense of Hinduism. In a manner wholly alien to Indian religion, the Italian had distinguished between civil and spiritual spheres and identified the latter with the "wise," by whom he meant mostly the Brahmins. Nobili despiritualized the Brahmins by presenting them largely as scientific experts, that is, as worthy but empty receptacles for the rational version of Christianity that he intended to preach to them. He did this not because he actually believed that Hinduism was spiritually vacuous (like all

$5^{1} \quad$ Murr, Indologie du père Coeurdoux, 156.

$5^{2}$ On the various uses of the word 'Vaikuntha', or Vishnu's heaven, and its derivatives in the Kristapurāṇa, see Falcao, Kristapurāṇa, a Christian-Hindu Encounter, xxvii, 181, 183, 189, 198, 201, and 206. 
Jesuits, he saw the Hindu gods as satanic), ${ }^{53}$ but in order to defend his position during the Malabar rites controversy, when he stood accused of allowing demonic rites among his Christian neophytes. In his view, converts to Christianity should be able to continue observing certain practices that prevented them from being expelled from their castes - a "trial more difficult" than death for Indians since, aside from enduring social rejection, caste outcasts were denied basic necessities like fire and water. ${ }^{54}$ The practices permitted included, first, the wearing on the forehead of the vidyavardhanam that is the mark of knowledge but also of the devotees of Vishnu, and which Nobili compared to the cap of European doctors and the fan of Chinese scholars; second, the wearing on the forehead of the tilakam or mark made with sandal paste that, Nobili maintained, was primarily decorative and only secondarily religious (in fact, it alludes to Shiva and Vishnu);55 third, the wearing over the left shoulder of the pūnūl or sacred thread that Brahmin boys received during their Upanayana ceremony, a custom that Nobili argued was too widespread among the high castes to be abandoned by Christians; and finally, the wearing on a man's head of the kudumi or hair tuft on a shaved head, which Nobili explained as being purely a mark of distinction for "the aristocracy" 56 and lacking all "superstitious" significance - though to this day brahmacharis shave their head to impulse the movement of shakti or spiritual energy up the spine and toward the head, while those who leave a hair tuft do so to prevent the soul from leaving the body through the sahasrar or topmost chakra in the event that spiritual energy becomes too intense following spiritual exercise.

Unlike Nobili, the compilers of the Lettres édifiantes had no motivation to remain silent about the fact that, in their view, the Hindu gods were demons. "A few years of experience," wrote Calmette, "has rendered us docile" on the subject of possession. ${ }^{57}$ It was only when Cœurdoux had to make Jesuit Indianism scientifically respectable in an enlightened context-just as Nobili had tried to make Hinduism decent in a religious polemical one- that India was again despiritualized. Like Nobili's exegetical treatises, Mours et coutumes deemed the Brahmins to be spiritually hollow. After all, their ritual zeal diminished when unobserved by other Brahmins, ${ }^{58}$ and in any case, "most [things]

\footnotetext{
53 Stephen Neill, A History of Christianity in India: The Beginnings to 1707, 300.

54 Lettres édifiantes, 13: 353 * $^{*}$

55 Lettres édifiantes, 13: $185{ }^{*}$

$56 \quad$ Lettres édifiantes, 13: 173. ${ }^{*}$

57 Lettres édifiantes, 13: 398.*

58 Courdoux, Moeurs et coutumes, 67-68.
} 
that are the object of the BRAHMINS' practices" were "frivolous things." 59 The dual difference between Nobili and Cœurdoux was that, whereas the first distinguished between civil and religious spheres, the second conceived of Indian social reality as seamlessly holistic, and that whereas Nobili the literatus emphasized the Brahmins' intellect, Cœurdoux the ethnographer underscored their "polished" qualities - the very ones that made them the cogs and lubricant of India's ritual, providential, and ultimately beautiful socialconstitutional machine.

The role of rituals as effective organizers of community is precisely that of the sacraments in Catholicism, but it is also a social corollary of rituals' cosmic role in Brahmanism. In this respect, Cœurdoux's subject matter harmonized with, and probably influenced, his methodology. The detailed and minutely prescribed action of ritual and sacrifice was as existentially primary and as generative of order in his ethnography as it was in the Vedic ethic that the Brahmins professed, functioning to maintain order, and the individual's relationship to that order, under optimal conditions. ${ }^{60}$ Certainly, Courdoux the Catholic missionary of the Age of Enlightenment made it a point to condemn Brahmin ceremonies as absurd. ${ }^{61}$ Yet this condemnation did not detract from his sociological intuition that, spiritually vacuous though they might be, Brahmin sacrifices maintained the social order and created civilization: for order requires complexity and civilization flourishes through rules. "These ceremonies," he observed, "have at least this advantage, that they oblige the BRAHMINS to meet Often and render Each Other reciprocal duties, and that they make of them a nation much more polished than the rest of the Indians." ${ }^{2}$ Thus, the Brahmanic idea of ritual as cosmic maintenance became in Cœurdoux's text the early anthropological notion of ritual as social maintenance and civilizational generation.

Cœurdoux perhaps best expressed the conservatism inherent in this perspective when describing India's complex caste system, which he praised for

59 Courdoux, Mours et coutumes, 70.

6o On Vedic sacrifice, see J. C. [Jan Cornelius] Heesterman, The Broken World of Sacrifice: An Essay in Ancient Indian Ritual (Chicago: University of Chicago Press, 1993).

61 Cœurdoux, Mours et coutumes, 42, 48, 70, 111.

62 Cœurdoux, Mours et coutumes, 30. 
"conserving the arts and perfecting them Without the avarice of Princes,"63 and for "conserving [...] good mores, repressing vices, [and] preventing Indians from falling into barbarity" in "a country, where Princes involve themselves very little in the police of mores." ${ }^{\prime 4}$ This providential functionality that Courdoux appreciated in the Indian order he discerned as well in Hindu religious consciousness. Hinduism, he realized insightfully, is a cult of whatever is useful, for even the gods are worshipped for the good and harm that might come from them. As the divulger of a religion that taught the propitiation of the saints, utilitarian worship can only have been familiar to him, but the Hindus went so far, he noted, as to worship their tools ${ }^{65}$ - a reference to the festival of Vijayadashami, the "Day of Victory" that follows the nine days of Navaratri dedicated to the Goddess when Hindus worship the instruments of their trade. Interestingly, in thus introducing ideas of social functionality into his text-ideas that were themselves already present in the Hindu religiosity he studied-Courdoux prefigured by over a century the functionalist notions that would become foundational to the sociology of Émile Durkheim (18581917) and the anthropology of Alfred Radcliffe-Brown (1881-1955). In a real sense, in fact, Christian providentialism - and in the case of Indology, the sacred Hindu utilitarianism it mirrored - was the theological ancestor of social functionalism. Cœurdoux, for his part, was among the first to lend to the idea of providence a social scientific character.

If Cœurdoux admired the castes for playing the role of a moral police, he also considered it fitting that the most polished caste should preside over the whole social order and that the pariahs should be kept down, since, among other things, they beat their pregnant wives when drunk. ${ }^{66}$ In this regard Christian natural law converged with the Hindu belief in the operation of karmic retribution across rebirths to justify the caste system. Acquiescence with existing social hierarchies was also typical of the Lettres édifiantes, where Father Bourzes wrote: "As everywhere there are mountains and valleys, rivers and streams, everywhere and in the Indies, more than elsewhere, one sees rich and poor, people of high birth, and others whose birth is vile and obscure."67

Not all social hierarchies, however, seemed equally natural to the Jesuits. Only those that were sufficiently ancient and genuinely native bore in their eyes God's stamp of approval. Thus, whilst Cœurdoux naturalized the

\footnotetext{
63 Courdoux, Mours et coutumes, 9.

64 Courdoux, Mours et coutumes, 8.

65 Courdoux, Mours et coutumes, 134-35.

66 Courdoux, Mours et coutumes, 173.

67 Lettres édifiantes, 12: 59.
} 
pariahs' subjection, he regretted that the Moghuls oppressed India's peoples, and though as a Frenchman he saw the stellar ascent of Hyder Ali Khan (r.1761-82) as a welcome brake on English conquests, he could not but exclaim: "Unhappy country where intelligence, courage and strength seem to give a man the right to dare and undertake everything!" Indeed, Cœurdoux disapproved strongly of the fact that Hyder Ali had become sultan after having been merely the Houkahbourdar, or officer responsible for carrying the pipe, of the Raja of Mysore ${ }^{68}$ — an unnatural ascent entirely suitable to the "perfidy" of his character. Hyder Ali's story is one of the few instances where Moeurs et coutumes becomes historical and a temporal dimension disrupts the synchronicity of the text. Inherently corrupting, the story interrupts the text just as it has upset the timeless, natural and divinely ordained India the rest of Mours et coutumes describes, an India regulated by Brahmin ritual and innocent of upstarts and foreign conquerors where society functions as God originally designed and intended it. It is an India that exists in tension with the India of the Jesuits' enlightened critique, replete with social problems like extreme poverty, political oppression, ${ }^{69}$ women's enslavement, and foreign rule.

In this last regard, and taking further Father Lalane's remark in the Lettres édifiantes that the Mughals exploit the Hindus economically, ${ }^{70}$ Cœurdoux comments that the Mughal India of his day has become a lawless and chaotic land oppressed by "[a] thousand tyrants, instead of one." ${ }^{71}$ His criticisms, however, are not limited to the Mughals or even to Oriental empires because he adds that even Mughal India is surpassed in evils by the "methodical Tyranny" of British India. ${ }^{72}$ These comments were probably motivated in part by French resentment over the Anglo-French Wars of $1744^{-63}$, which effectively eliminated French power in India, but what is certain is that Cœurdoux never developed them into a general critique of imperialism. He remained silent on the Portuguese empire and, far from calling for his own country's withdrawal from the Subcontinent, recommended that France should expel the British in order both to free the Indians, and to enable other European powers to remain in the Subcontinent. Of course, Courdoux warned, whatever nation tore the "scepter of Asia" away from the English should remember "above All to make the Indians forget by Its goodwill, Its moderation and its humanity the injustices,

\footnotetext{
68 Courdoux, Mours et coutumes, 187.

69 Lettres édifiantes, 13: 204.*

$70 \quad$ Lettres édifiantes, 11: 212-13, 215-16.*

71 Cœurdoux, Mours et coutumes, 187.

72 Cœurdoux, Mours et coutumes, 189.
} 
the banditry and the cruelties of the English."73 This said, Courdoux's advice does not seem to have amounted to a recommendation that the French take over the whole of India. It would have contradicted the belief he shared with his fellow Jesuits that a nation is well-governed, regardless of how hierarchically, only when it is so by its divinely appointed, age-old rulers.

The ideal of a moral order implied by this opinion explains the text's lack of attention to politics and economics, along with its subordination of these fields to morality. It was, once again, an anticipation of later sociological ideas, specifically those of the precursors of French sociology Joseph de Maistre (1753-1821), Louis de Bonald (1754-1840), and Auguste Comte (1798-1857) ${ }^{74}$ For these thinkers as for Courdoux, the supreme secular knowledge was not that of the political realm that disturbs the natural order, but that of the social and moral relations that best reflect God's mind—or, in Comte's case, the mind of Humanity divinized.

\section{6}

\section{A Theory of Origins}

The question then becomes: why did Cœurdoux's providentialism not allow him to see changes of superiors as themselves providentially prescribed? The answer lies in the speculative sacred history that provides the untold backdrop to Moeurs et coutumes' otherwise synchronic account. In 1768-eighteen years before Sir William Jones (1746-94), who is usually credited with the discovery of proto-Indo-European - Cœurdoux wrote a memoir to the Académie des Inscriptions et Belles-Lettres where he offered a theory of Brahmin origins that posited - if not the existence of proto-Indo-European as a mother languageat least that of an "ancient mix" of languages that included Sanskrit and Europe's founding tongues. He wrote:

The Sanskrit language is that of the ancient Brahmins; they arrived in India, from [lands] north of that country, from the Caucasus, from Tartary, which was populated by the descendants of Magog. Of the children of Japheth, some spoke Greek, others Latin, others Sanskrit. Before their total separation, the communication they had together, mixed their

73 Cœurdoux, Mours et coutumes.

74 On the subordination of politics to morality by early Francophone precursors of sociology, see Carolina Armenteros, "The Counter-revolutionary Comte: Theorist of the Two Powers and Enthusiastic Medievalist," in A Comte Anthology, ed. Andrew Wernick (London: Anthem Press, 2017), 91-116. 
languages a bit; and traces have remained of this ancient mix, in the common words that subsist still, and of which I have reported a portion. ${ }^{75}$

Following the Deluge (Cœurdoux argued against Voltaire who rejected the Deluge), Magog, the second son of Japheth, left the plains of Shinar ${ }^{76}$ and settled in the Caucasus before some of his descendants migrated to the Indian Subcontinent, bringing with them a primitive version of Brahmin culture. It was a biblical hypothesis designed to support the kind of argument that the veteran Jesuit missionary and superior of the Malabar missions, Jean-Venant Bouchet (1655-1732), had made in 1730 to the French scholar Pierre-Daniel Huet (1630-1721), whose Demonstratio evangelica (Evangelical demonstration) (1679) argued that paganism was but a collection of the corrupted remnants of the biblical revelation. In a letter to Huet, Bouchet had argued that the Indian case fit this thesis, as various Indian gods and myths recalled biblical figures and stories, notably the virtous King Harischandra, cursed by sage Vishwamitra to endure the greatest griefs and most vile ignominies, and who was none other, in Bouchet's estimation, than the Indian Job. ${ }^{77}$ Voltaire had had no trouble ridiculing this letter and its far-fetched speculations. ${ }^{78}$ Yet Cœurdoux's ordered and erudite description of Brahmin mores, framed by his speculative yet linguistically supported history of the migration of Magog's descendants to India, left open the possibility that Hindu culture had a remote biblical ancestry in a manner more difficult to knock down.

Cœurdoux's theory of the descent from the Caucasus thus contradicted Voltaire (who had argued, against the Bible, for the Indians' extreme antiquity) by affirming that the Indians were indeed ancient as the philosopher had claimed, yet still biblical as he had denied. On the subject of India's antiquity, Cœurdoux also sided with Nicolas Fréret (1688-1749) and Abbé Vincent Mignot (1725-91) against his fellow Indianist Jesuits, Calmette and Bouchet, by insisting provocatively that the ancient Greeks had traveled to India to learn from its philosophers, so that India was the origin of European civilization and not the other way around. Keen, furthermore, to wrest the torch from Greek and Roman authors who were still the authorities on India in France's

\footnotetext{
75 Quoted in Murr, Indologie du père Coeurdoux, 36.

76 The Septuagint's name for Mesopotamia.

77 Bouchet's letter to Huet first appeared in the Lettres édifiantes 9: 1-60.* Its English translation was published in David J. A. [John Alfred] Clines, "In Search of the Indian Job," On the Way to the Postmodern: Old Testament Essays 1967-1998, 2 vols. (Sheffield: Sheffield Academic Press, 1998), 2: 770-91.

78 Murr, Indologie du père Coeurdoux, 174.
} 
academies, Cœurdoux highlighted that "the ancient authors have spoken about India with less exactitude [...] than the modern ones [les nouveaux]."79 Through this claim, Courdoux contributed to another debate that replicated, in regard to Oriental subjects, in the middle of the eighteenth century and within the Académie des Inscriptions et Belles-Lettres, the dispute on the relative merits of the ancients and the moderns that had raged at the end of the seventeenth. In this debate Cœurdoux sided with Fréret, Abbé Jean-Jacques Barthélemy (1716-95) and Anquetil-Duperron-all of whom encouraged the gathering of new knowledge about India-but he went further than all of them by urging the study of Sanskrit and the Indian vernacular languages, in addition to trips to India and consultation with Indian experts. ${ }^{80}$ In doing this, Cœurdoux became the first and most ardent defender of Indianism as a modern discipline emancipated at last from ancient Greek and Roman referents.

The biblical frame of reference aside, the theory of the migration of Magog's descendants to India has been borne out by science, as the PonticCaspian steppe immediately north of the Caucasus that most scientists today believe to have been the home of the proto-Indo-Europeans is located in what was once called Tartary, the land that Courdoux invoked, together with the Caucasus, as the home of Magog's children, while the latest genetic studies argue for "a formative Caucasus influence" on the Yamna Bronze Age culture that is considered to be the likeliest candidate for the Urheimat of the protoIndo-Europeans. ${ }^{81}$ As well, Indianists continue to maintain that the peoples who migrated from that region into India, bringing Sanskrit and the culture of Vedic sacrifice with them, were none other than the Brahmins' ancestorsprecisely Courdoux's position. ${ }^{82}$ Unfortunately, though, the destiny of this retiring missionary was to be effaced from the history of scholarship: probably due to his Jesuit status, the Académie des Inscriptions et Belles-Lettres to which he sent his memoir on the Brahmins' Caucasian and Tartarian origins did not read it in public for eighteen years, nor publish it for another forty after

79 Murr, Indologie du père Coeurdoux, 118.

80 Murr, "Les conditions d'émergence du discours sur l'Inde au siècle des Lumières," Purușārtha 7 (1983): 233-84, here 251.

81 See Eppie R. Jones, "Upper Paleolithic Genomes Reveal Deep Roots of Modern Eurasians," Nature (2015), 6: 8912; doi: 10.1038/ncomms9912 (accessed May 29, 2019).

82 This was, at least, the position of Michel Angot in "Il n'y a jamais eu l'Inde', mais 'des' Indes," https://www.lexpress.fr/actualite/monde/asie/michel-angot-il-n-y-a-jamais-eul-inde-mais-des-indes_1204727.html (accessed May 29, 2019) and that of Hamilton in Indian Philosophy, 18-19. Michael Witzel however observes that our knowledge of the Brahmins before the first millennium is "fragmentary" and "preliminary." See "Toward a History of the Brahmins," Journal of the American Oriental Society 113, no. 2 (1993): 264-68. 
receiving it. ${ }^{83}$ The result is that Sir William Jones is usually cited as the father of Indo-European studies and comparative linguistics, and that Cœurdoux's original proposition of the Brahmins' Central Asian origins is not mentioned by anyone, not even by Murr.

If examining the great works of eighteenth-century philosophy convinced Duchet that anthropology had resulted from an "internal transformation of the sensualist system," the case of Moeurs et coutumes demonstrates the very different picture that emerges when one examines how anthropological discourses formed in the field, through immersion in local cultures, and as heirs of longstanding local interpretive traditions. It is then that one becomes aware of the deeply spiritualist and providentialist concepts that informed early Jesuit missionary Indology. It is then too that one can see where Descartes, Montesquieu, and Voltaire end, and where the Vedas and Brahmanic ritual begin. That is, it is posible to discern Indian culture's own contribution to the development of Indology, an evident yet neglected fact in a field that remains Eurocentric in character. And finally, it is only then that one can discern how a founding opus like Cœurdoux's was less the spontaneous transformation of philosophy into science, than the result of a careful process of inclusion and exclusion of themes, approaches, and methodologies developed by field scholars over centuries of study, and through involvement with cultures that they intimately knew. In this sense, understanding early anthropology entails examining less the great works of mainstream philosophy, than the forgotten minora of field scholarship.

Expression through minora is one connection between missionary anthropology and enlightened conservatism, which had flourished already in the Lettres édifiantes, but was fully consecrated in Moeurs et coutumes. The preference for order over freedom; the acceptance of traditional hierarchy vis-à-vis

83 See Rosane Rocher, "The Knowledge of Sanskrit in Europe until 180o," in History of the Language Sciences: An International Handbook on the Evolution of the Language Sciences from the Beginning to the Present, ed. Sylvain Auroux, E. F. K. [Ernst Frideryk Konrad] Koerner, Hans-Josef Niederehe, and Kees Versteegh, 3 vols. (Berlin: Walter de Gruyter, 2001), 2: 1156-59. On the Jesuits' importance in the formative years of the Académie des Inscriptions et Belles-Lettres, and their marginalization by the mid-eighteenth century, see Florence Hsia, Sojourners in a Strange Land:Jesuits and their Scientific Missions in Late Imperial China (Chicago and London: The University of Chicago Press, 2009). 
the philosophic liking for equality; the scepticism regarding empire in an age that often affirmed colonization; ${ }^{84}$ the preservation of classical erudition in the face of the Encyclopédie's technical empiricism; the spite for myth and poetry as the expressions of an imagination gone wild; the concomitant interest in ordinary life vis-à-vis high culture; the valorization of rituals and action at the expense of intellectual productions; and the discarding of the idea that history, literature, and science are the best means of understanding culture, were so many traits of enlightened conservatism and the early conservative ethic that distinguish Moeurs et coutumes from the mainstream Enlightenment philosophy that is traditionally considered as having given birth to anthropology. ${ }^{85}$

In this connection, it is suggestive that the same year that he converted to Catholicism and that (coincidentally) the Académie des Inscriptions et Belles-Lettres at last published the memoir where Courdoux theorized the migration of Magog's descendants to India, the German Romantic Friedrich Schlegel (1772-1829) published his blockbuster Über die Sprache und Weisheit der Indier (On the language and wisdom of the Indians) (1809). Unlike Cœurdoux, who advanced what we now call the Indo-Aryan migration theory - the most widely accepted theory of Indian linguistic origins-Schlegel was a proponent of the Indigenous Aryans theory, or the idea that European languages and civilizations originated in India rather than in the Caucasus and nearby regions. Yet Courdoux also insisted on Europe's civilizational debt to India, as we have seen, and Schlegel elaborated a spiritualist version of this position. $\mathrm{He}$ wrote of a "primitive revelation," a revelation complementary to the Bible that humanity had received in remote antiquity and that India's sacred scriptures

84 Sankar Muthu's Enlightenment against Empire (Princeton: Princeton University Press, 2003) argues that, although the Enlightenment is usually considered to have been imperialistic, eighteenth-century political thought contained multiple Enlightenments, one of which—represented by Diderot, Kant, and Herder — was anti-imperialist. Suggestively for the present argument, however, the last of these thinkers has been associated with the Counter-Enlightenment—itself closely associated with enlightened conservatism — since the concept was first invented. From a different perspective, Blandine Kriegel has suggested that, as opposed to the thought of the Holy Roman Empire, early modern French and British political thought was anti-imperialist. See "Les monarchies contre l'empire?: Légistes et penseurs politiques des monarchies anglaises et françaises de la Renaissance et de l'Âge classique, critiques du droit et de l'idée impériale; Que nous apprennent-ils sur la nature de la monarchie?," paper presented at the conference "Monarchy and Modernity since 1500," University of Cambridge, January, 8-9, 2019.

85 These are, interestingly, all traits found as well in the thought of the passionate philoJesuit and founder of conservatism Joseph de Maistre (1753-1821). See my French Idea of History. 
preserved most purely. Heinrich Heine (1797-1856) perceptively identified this last argument as ultramontanism in disguise. "These good people," he recalled regarding Schlegel and his enthusiastic followers,

had not only discovered the mysteries of the Roman priesthood in Indic poetry, but all its hierarchy and all its struggles with temporal power as well. In the Mahabharata and the Ramayana they see the Middle Ages in elephantine form. Indeed, in the Ramayana the struggle between the king Vishvamitra and the priest Vashishta involves all the same stakes which set emperor against pope: here in Europe the object of the dispute was called investiture; in India it was the cow Sabala. ${ }^{86}$

The comment, made with Heine's characteristic irony, does not convey just how vigorously the publication of Über die Sprache shook German intellectual life, generating multiple careers along with furious opposition. ${ }^{87}$ That a book on India's ancient cultural and religious identity could have an impact at once so fruitful and divisive in nineteenth-century Europe is certainly thoughtprovoking. It shows how the non-European cultures and traditions that entered European consciousness through these debates did so in an atmosphere that, once enlightened, had by the early nineteenth century become ultramontanist and politically conservative. ${ }^{88}$

86 Heinrich Heine, Die Romantische Schule (1836), quoted in Raymond Schwab, The Oriental Renaissance: Europe's Rediscovery of India and the East, 1680-1880, trans. Gene PattersonBlack and Victor Reinking (New York: Columbia University Press, 1984), 75.

$87 \quad$ Schwab, Oriental Renaissance, 74 .

88 I would like to express my gratitude to Dan Edelstein and the audience at Stanford's French Culture Workshop for their helpful comments on an early draft of this paper. 